\title{
Metabolic and endocrinologic complications in beta-thalassemia major: a multicenter study in Tehran
} Alireza Abdollah Shamshirsaz*1,2, Mir Reza Bekheirnia1,2, Mohammad Kamgar1,2, Nima Pourzahedgilani ${ }^{1}$, Navid Bouzari1 Mohammadreza Habibzadeh ${ }^{1}$, Reza Hashemi ${ }^{1}$, Amirhooshang Abdollah Shamshirsaz ${ }^{3}$, Shahriar Aghakhani ${ }^{1}$, Hooman Homayoun ${ }^{2}$ and Bagher Larijani ${ }^{1,2}$

\author{
Address: ${ }^{1}$ Endocrinology and Metabolism Research Center-Tehran University of Medical Sciences and Health Services, Iran, ${ }^{2}$ Charity foundation \\ for special diseases, Iran and ${ }^{3}$ Shahid Beheshti University of Medical Sciences and Health Services, Iran \\ Email: Alireza Abdollah Shamshirsaz* - alirezashamshirsaz@yahoo.com; Mir Reza Bekheirnia - rezabkh@hotmail.com; \\ Mohammad Kamgar - m_kamgar@yahoo.com; Nima Pourzahedgilani - nimapg@yahoo.com; Navid Bouzari - nbouzari@yahoo.com; \\ Mohammadreza Habibzadeh - mrezahabibzadeh@yahoo.com; Reza Hashemi -r_hashemi@hotmail.com; \\ Amirhooshang Abdollah Shamshirsaz - shamshir_a1978@yahoo.com; Shahriar Aghakhani - aghakhani@parsonline.net; \\ Hooman Homayoun - alirezashamshirsaz@yahoo.com; Bagher Larijani - emrc@sina.tums.ac.ir \\ * Corresponding author
}

Published: 12 August 2003

BMC Endocrine Disorders 2003, 3:4 doi:10.1/86/1472-6823-3-4

This article is available from: http://www.biomedcentral.com/I472-6823/3/4

(C) 2003 Abdollah Shamshirsaz et al; licensee BioMed Central Ltd. This is an Open Access article: verbatim copying and redistribution of this article are permitted in all media for any purpose, provided this notice is preserved along with the article's original URL.

\begin{abstract}
Background: The combination of transfusion and chelation therapy has dramatically extended the life expectancy of thalassemic patients. The main objective of this study is to determine the prevalence of prominent thalassemia complications.

Methods: Two hundred twenty patients entered the study. Physicians collected demographic and anthropometric data and the history of therapies as well as menstrual histories. Patients have been examined to determine their pubertal status. Serum levels of $25(\mathrm{OH}) \mathrm{D}$, calcium, phosphate, iPTH were measured. Thyroid function was assessed by T3, T4 and TSH. Zinc and copper in serum were determined by flame atomic absorption spectrophotometry. Bone mineral density (BMD) measurements at lumbar and femoral regions have been done using dual x-ray absorptiometry. The dietary calcium, zinc and copper intakes were estimated by food-frequency questionnaires.

Results: Short stature was seen in $39.3 \%$ of our patients. Hypogonadism was seen in $22.9 \%$ of boys and $12.2 \%$ of girls. Hypoparathyroidism and primary hypothyroidism was present in $7.6 \%$ and $7.7 \%$ of the patients. About $13 \%$ of patients had more than one endocrine complication with mean serum ferritin of $1678 \pm 955$ micrograms/lit. Prevalence of lumbar osteoporosis and osteopenia were $50.7 \%$ and $39.4 \%$. Femoral osteoporosis and osteopenia were present in $10.8 \%$ and $36.9 \%$ of the patients. Lumbar BMD abnormalities were associated with duration of chelation therapy. Low serum zinc and copper was observed in $79.6 \%$ and $68 \%$ of the study population respectively. Serum zinc showed significant association with lumbar but not femoral BMD. In $37.2 \%$ of patients serum levels of $25(\mathrm{OH}) \mathrm{D}$ below $23 \mathrm{nmol} / \mathrm{l}$ were detected.
\end{abstract}

Conclusion: High prevalence of complications among our thalassemics signifies the importance of more detailed studies along with therapeutic interventions. 


\section{Background}

Beta-thalassemia represents a group of recessively inherited hemoglobin disorders first described by Cooley and Lee [1] and characterized by reduced synthesis of $\beta$-globin chain. The homozygous state results in severe anemia, which needs regular blood transfusion. The combination of transfusion and chelation therapy has dramatically extended the life expectancy of thalassemic patients who can now survive into their fourth and fifth decades of life $[2,3]$ On the other hand, frequent blood transfusion in turn can lead to iron overload which may result in hypogonadism, diabetes mellitus, hypothyroidism, hypoparathyroidism and other endocrine abnormalities [4]. In recent years, several authors reported a high incidence of endocrine abnormalities in children, adolescents and young adults suffering from thalassemia major. However the incidence of the various endocrinopathies changes among different series of the patients due to a mixture of reasons other than iron overloads [5].

Osteoporosis is common even in well-treated thalassemic patients [6]. There are no data reflecting the bone mineral density status of Iranian thalassemic patients. Trace metals deficiencies in patients with thalassemia major have been under debate $[7,8]$. Trace minerals have been shown to influence growth and hormones at several levels, and zinc deficiency which may be considered a causative factor for osteoporosis and endocrinopathies [9] have not been fully studied in our patients yet.

In our country, there are more than 20,000 thalassemic patients. We have conducted this study to establish the pattern of endocrine function, bone changes and nutritional status in Iranian thalassemic patients.

\section{Methods}

Thalassemic patients in Tehran are all registered in 12 clinics in order to receive treatment. These clinics were ordered in a list according to the number of registered patients. From every two consecutive centers, one was selected with simple random method in order to select six thalassemia clinics. Number of patients to be selected from each clinic was calculated with proportional to size method based on registered cases in each of these clinics. In each clinic, patients were selected with simple random method by using computerized tables. Two hundred fifty eight adolescent homozygous beta-thalassemia patients were recruited, among whom, 220 (51.5\% male) accepted to enter the study. Table 1 shows demographic data of the study population. The diagnosis of homozygous thalassemia was based on the usual hematological criteria (peripheral blood evaluation and hemoglobin electrophoresis of the patients) from early years of life. Informed consent was obtained from the patients or their parents (in non-competent patients). The study protocol was
Table I: Demographic characteristics of study population (Mean \pm SD)

\begin{tabular}{ll}
\hline Age & $15.2 \pm 3.1(\mathrm{yr})$ \\
Height & $146.9 \pm 12.3(\mathrm{~cm})$ \\
Weight & $39.6 \pm 9.7(\mathrm{~kg})$ \\
Height for age (HAP) & $13.2 \pm 17.8$ \\
Weight for age (WAP) & $11.9 \pm 15.1$ \\
BMI & $18.3 \pm 3\left(\mathrm{~kg} / \mathrm{m}^{2}\right)$ \\
\hline
\end{tabular}

Table 2: Therapeutic characteristics of study population (Mean \pm SD)

\begin{tabular}{ll}
\hline Age of start of transfusion & $15.4 \pm 18.8$ (month) \\
Age of start of desferrioxamine & $5.1 \pm 3.1(\mathrm{yr})$ \\
Pretranfusion hemoglobin in last year & $9.6 \pm 2.3(\mathrm{~g} / \mathrm{dl})$ \\
Ferritin & $1441 \pm 1 \mathrm{III.3( \mu \textrm {g } / \mathrm { l } )}$
\end{tabular}

approved by the ethics committee of Tehran University of medical sciences-research deputy.

Physicians collected demographic and anthropometric data and the history of menstruation, family history of diabetes, initiation and duration of blood transfusion, as well as chelation therapy. Percentiles of height and weight were determined by growth diagram provided by National Center for Health Statistics (NCHS). Puberty status according to Marshall-Tanner [10] determined. Characteristics of study group are shown in table 1 and 2 . All subjects were transfused every 4-5 weeks with packed red cell since early years of life in an attempt to keep their pretranfusion hemoglobin above $9.5 \mathrm{~g} / \mathrm{dl}$. Our patients were taking $20-50 \mathrm{mg} / \mathrm{kg}$ daily desferrioxamine as iron chelator. Therapeutic markers of the study population are depicted in table 2. Splenectomy had been performed on 107 of our patients (mean age of splenectomy: $9.2 \pm 4.1$ yr). Blood samples were drawn from patients after they had fasted. Serum samples were stored at $-20^{\circ} \mathrm{C}$ until analyzed. Serum $25(\mathrm{OH})$ D was measured by radioimmunoassay (iDS, UK). Serum iPTH concentrations were measured by use of an immunoradiometric method (Ntact, DiaSorin, USA) Zinc and copper in serum were determined by flame atomic absorption spectrophotometry. Serum level of zinc and copper was measured using atomic absorption spectrophotometry. Serum zinc level less than $70 \mu \mathrm{g} / \mathrm{dL}$ was regarded as low [11]. Serum copper levels were normal if above 70 and $80 \mu \mathrm{g} / \mathrm{dL}$ for boys and girls respectively [12]. Serum ferritin level was measured by standard methods (microparticle enzyme immunoassay). 
The dietary calcium, zinc and copper intakes were estimated by use of food-frequency questionnaires (FFQ). We measured lumbar spine (L1-L4) and femoral area bone mineral density (BMD) $\left(\mathrm{g} / \mathrm{cm}^{2}\right)$ in 212 patients, using dual-energy X-ray absorptiometry (LUNAR, DPXMD\#7164), which was calibrated daily. Osteopenia is defined as T score between -1 to -2.5 , and osteoporosis below -2.5 by W.H.O (1994) criteria. This definition relates to adult women and not to children, adolescents, men and the very old. Thus we defined osteopenia, as $Z$ score between -1 to -2.5 , and osteoporosis below -2.5 [13].

Hypogonadism was indicated by absence of breast development in girls and absence of testicular enlargement in boys (less than $4 \mathrm{ml}$ ) as measured by Prader's orchidometer by the age of 16 [14]. Impaired puberty was defined as more than 2 SD delay in pubertal development beyond the mean for their sex. Irregular menstrual cycles were characterized by an unpredictable and variable interval between menses which always occurred more frequently than every 3 months. Primary amenorrhea was present when the menarche has not appeared by the age of 16 or lack of breast development by the time when a girl was 14 . Secondary amenorrhea was defined as the absence of menstruation for a 6 months period at any time after menarche. Body mass index (BMI) was calculated with the following formula; $\mathrm{BMI}=$ weight $(\mathrm{kg}) /$ height $^{2}\left(\mathrm{~m}^{2}\right)$. Patients' evaluation for endocrine complications was performed annually. Bone mineral density measurement and determination of serum zinc and copper are not components of routine patients' workup. Thyroid function was assessed by T3, T4 and TSH, using commercial radioimmunoassay (RIA) to determine these parameters. Hypothyroidism was defined according to Evered et al [15], or based on the history of treatment with levothyroxine for previously diagnosed hypothyroidism. Hypoparathyroidism was diagnosed when there was low serum calcium concentration, which was measured increased serum phosphate, low serum parathyroid hormone (with a reference range of $13-54 \mathrm{pg} / \mathrm{ml}$.), or if normal, a PTH level inappropriate for the calcium level. Patients with diabetes mellitus based on the history of insulin therapy have been recognized (glucose tolerance test (GTT) has not been performed).

Data were analyzed by using Statistical Package for Social Sciences (SPSS) software (version 10.0). Numerical data are presented as mean \pm standard deviation. $\mathrm{P}<0.05$ was considered significant. All factors were tested for their distribution model. We considered Mann-Whitney and Kruskal Wallis tests, where distributions were not normal, to investigate different levels of associations. Simple linear regression has been used to show the correlation of serum
Table 3: Prevalence of pubertal disorders and menstrual abnormalities in thalassemic patients

\begin{tabular}{ll}
\hline Disorder & Prevalence (\%) \\
\hline $\begin{array}{l}\text { Impaired puberty } \\
\quad \text { females }\end{array}$ & 72.6 \\
$\quad$ males & 80.8 \\
Primary amenorrhea & 32.8 \\
Irregular menstrual cycle & 43 \\
Hypogonadism & \\
$\quad$ females & 12.2 \\
$\quad$ males & 22.9 \\
Short stature & 39.3 \\
\hline
\end{tabular}

zinc and lumbar BMD. All the statistical analysis has been done with 95\% confidence interval, when appropriate.

\section{Results}

\section{Endocrine abnormalities}

In our study population, $80.8 \%$ of boys and $72.6 \%$ of girls had impaired puberty. Serum ferritin level in this group was $1407 \pm 971 \mu \mathrm{g} / \mathrm{l}$, which was not statistically significant in comparison with patients who went normally through puberty. Hypogonadism was seen in $22.9 \%$ of boys and $12.2 \%$ of girls (no significant difference) with the mean serum ferritin level equal to $1787 \pm 988 \mu \mathrm{g} / \mathrm{l}$ that was significantly higher than patients without hypogonadism $(P=0.036)$. The mean age at the time of menarche was $15.3 \pm 1.7$ years. Prevalence of primary amenorrhea was 32.8 percent (19 out of 58). Serum ferritin level was significantly higher in this group of patients than those who experienced mense in time $(P=0.008)$. Among 39 patients who experienced menarche, 17 and 3 had irregular mense and secondary amenorrhea, respectively. None of them were overweight. Mean of serum ferritin level in patients with irregular mense was $1527 \pm$ $1073 \mu \mathrm{g} / \mathrm{l}$, significantly higher than those with regular mense $(861 \pm 492 \mu \mathrm{g} / \mathrm{l})(\mathrm{P}=0.008)$. Prevalence of pubertal disorders is summarized in table 3. Short stature (height below the $3^{\text {rd }}$ percentile) was seen in $39.3 \%$ of our patients. Their serum ferritin level was not different from normal stature cases. There was no difference in prevalence of short stature between pre-pubertal and rest of the study population.

There were a total of $8.7 \%$ with history of diabetes mellitus and all of them except one had been diagnosed after the age of 10. The mean age at the time of diagnosis was $15 \pm 3$ years. No significant difference was seen between males and females in the prevalence of diabetes mellitus (61.1\% male, 38.9\% female). Serum ferritin level in thalassemic patients with diabetes $(1519 \pm 920 \mu \mathrm{g} / \mathrm{l})$ and those without history of diabetes were not significantly 
different. Sixteen percent of diabetic patients had a family history of type I or type II diabetes in their siblings, parents or grandparents. Four cases had been first presented with ketoacidosis.

Primary hypothyroidism was present in $7.7 \%$ of patients (with mean age of $16.4 \pm 4.1 \mathrm{yr}$ ). We had five patients with clinical hypothyroidism. Mean of ferritin was $1782 \pm$ $1824 \mu \mathrm{g} / \mathrm{l}$ in this group. There was no significant difference in mean serum ferritin between hypothyroid patients and others.

Hypoparathyroidism was found in $7.6 \%$ of patients. The mean age of these patients was $16.9 \pm 3.7$ years and the highest prevalence of hypoparathyroidism was seen in the age of 20 , with the distribution of $81.8 \%$ in males and $18.2 \%$ in females. The mean serum level of calcium and phosphate was $7.6 \pm 0.8 \mathrm{mmol} / \mathrm{l}$ and $4.4 \pm 1.0 \mathrm{mmol} / \mathrm{l}$ respectively. The mean serum ferritin level was $1444 \pm 798$ $\mu \mathrm{g} / \mathrm{l}$, not significantly different with other patients. Prevalence of endocrine complications is illustrated in figure 1.

About $10 \%$ of patients had more than one endocrine complication. The mean age of these patients was $18.4 \pm$ 1.3 years. There was a significant difference $(p=0.01)$ between mean serum ferritin in thalassemic patients with endocrine complications (one or more than one complication) $(1660 \pm 1208 \mu \mathrm{gr} / \mathrm{l})$ and thalassemic patients without endocrinopathies $(1166 \pm 823 \mu \mathrm{gr} / \mathrm{l})$.

\section{Metabolic abnormalities}

Prevalence of osteoporosis and osteopenia in the lumbar (L1-L4) region were $50.7 \%$ and $39.4 \%$ respectively. These figures showed osteoporosis and osteopenia as $10.8 \%$ and $36.9 \%$ in the femur neck. Concomitant lumbar and femoral osteoporosis was observed in $7.9 \%$, while only in $9.3 \%$ both regions were normal (above -1SD below the mean). There was no significant difference in prevalence of osteoporosis between boys and girls. The mean age of osteoporotic patients was significantly higher $(\mathrm{p}<0.05)$.

Mean serum zinc level was $54.6 \pm 4.0 \mu \mathrm{g} / \mathrm{dL}$. Serum zinc level was lower than normal (below $70 \mu \mathrm{g} / \mathrm{dL}$ ) in $79.6 \%$ of patients. Mean serum level of copper was found to be $65.1 \pm 3.9 \mu \mathrm{g} / \mathrm{dL}$. Serum copper level was lower than normal in $68 \%$ (less than $70 \mu \mathrm{g} / \mathrm{dL}$ in boys and $80 \mu \mathrm{g} / \mathrm{dL}$ in girls) of our patients. Daily intake of copper and zinc was lower than normal(less than $2-3 \mu \mathrm{g} /$ day and $15 \mu \mathrm{g} /$ day for copper and zinc) in $90.1 \%$ and $91 \%$ respectively. Serum zinc level was associated with lumbar $\left(\mathrm{R}^{2}=0.02, \mathrm{p}\right.$ $<0.05$ ) but not femoral BMD. We did not find any association between serum copper and BMD values.

Mean of daily calcium intake was $830.5 \mathrm{mg}$ (ranged from 221 to $3185 \mathrm{mg}$ ). Low calcium intake (less than $1200 \mathrm{mg} /$ day) was observed in $84.2 \%$ of our patients, not significantly different between genders. Mean of serum $25(\mathrm{OH})$ $\mathrm{D}$ level was $31.48 \mathrm{nmol} / \mathrm{l}$. In $37.2 \%$ of patients serum levels of $25(\mathrm{OH}) \mathrm{D}$ below $23 \mathrm{nmol} / \mathrm{l}$ (vitamin D deficiency on the basis of the reference range of manufacturer) was observed.

\section{Discussion}

Impaired puberty, which occurred in approximately $77 \%$ of our patients, was the most common endocrine abnormality. The prevalence of other endocrinopathies was much lower: $17.5 \%$ hypogonadism, $8.7 \%$ diabetes mellitus, $7.7 \%$ primary hypothyroidism, and $7.6 \%$ hypoparathyroidism. Three out of 39 postmenarchal patients had secondary amenorrhea. Impaired puberty seems to be more prevalent in our study compared to study of Italian working group [14]. Hypogonadism in our study was considerably lower than other studies. In a longitudinal study, prevalence of hypogonadism has been reported to be as much as $75 \%$ in girls and $62 \%$ in boys [16]. In our study diabetes was present in $8.7 \%$ of the patients. This is considerably higher than the $4.9 \%$ of patients developing IDDM in a recent study by the Italian Working Group [14]. It is unclear whether diabetes in $\beta$-thalassemia major is related to genetic factors $[14,16]$. It seems that our diabetic patients were of younger ages at the time of diagnosis in comparison with other studies [14,17]. Hypothyroidism was a complication in $7.7 \%$ of our patients. Thyroid dysfunction has been reported in 13$60 \%$ of patients with thalassemia, but its severity is variable in different series. Some studies reported a high prevalence of primary hypothyroidism, reaching up to $17-$ $18 \%[18,19]$, While others reported low prevalence of $0-$ $9 \%[20,21]$. It is important to note that even in the studies in which the prevalence of overt hypothyroidism as a complication of thalassemia major is relatively low, milder forms of thyroid dysfunction are much more common $[18,20,22]$, though again there are wide variations in different reports. These discrepancies can not be attributed to differences in patients' ages, but rather to difference treatment protocols, including differing transfusion rates and chelation therapies [21]. The prevalence of hypoparathyroidism observed in our study $(7.6 \%)$ is higher than the $3.6-7 \%$ reported by other workers $[5,14,23]$. The male/female ratio was $4 / 1$. This ratio is higher than other reports $[14,24]$.

Short stature seemed to be more prevalent among our patients compared to other studies [25]. Our growth assessments did not show any difference of short stature prevalence between prepubertal and pubertal patients, in contrast to the results of Pignatti et al who claimed growth abnormalities to be more prevalent in pubertal patients [26]. 
High prevalence of endocrine abnormalities was reported by several authors $[14,23,27]$. They demonstrated that these abnormalities were related to iron overload. The histological studies of different endocrine glands supported this hypothesis $[28,29]$. We found significant difference in mean serum ferritin level between thalassemic patients with primary amenorrhea, irregular mense, hypogonadism and those without endocrinopathies. These findings yield the importance of iron overload in development of endocrine disorders. In contrast, there are some other reports which have suggested no relation between the level of ferritin and some other endocrinopathies [30,31]. It has been suggested that the prognosis for survival is excellent for thalassemic patients with serum ferritin concentration below $2500 \mu \mathrm{g} / \mathrm{l}$ [32]. We found a considerable sum of endocrinopathies in our population. Taking into account that their ferritin levels are not of high amounts, it is possible, therefore, that there are other factors responsible for organ damage. Among these factors; liver damage due to viral infections, increased activity of the iron dependent protocollagen proline hydroxylase enzyme, chronic anemia and individual susceptibility to damage from iron overload have been previously pointed out[14].

High prevalence of osteoporosis and osteopenia in our thalassemic patients is in gross agreement with those reported in the earlier literature, although the diversity of the employed techniques weakens some of the comparisons. Similar results from other studies have also been reported [33,34]. Jensen et al studied 82 patients who were well transfused and who received regular desferrioxamine. In that study, the overall prevalence of patients with "severely low" bone mass was 51\% and those with "low" bone mass 45\% [35]. We did not find any significant difference between men and women, this finding was in agreement with the some previous reports [36,37] but was in contrast to the findings of Jensen et al who reported that the bone lesions in thalassemic are more frequent and more prominent in males [35]

Zinc deficiency is considered as one of the main factors contributing to growth and puberty disorders in thalassemic patients [38]. Our findings show serum zinc deficiency in around $80 \%$ and serum copper deficiency in about $68 \%$ of thalassemic patients studied. The zinc status of thalassemic patients was previously reported by Arcasoy et al and they showed that there was marked zinc deficiency in the presence of hyperzincuria [39]. Kwan and colleagues [16] reported that only 3 of their 68 thalassemic patients had zinc deficiency in their study population. Deficiencies of zinc and copper in patients with thalassemia major have been under debate. It seems that deficiency of serum zinc and copper in our patients could be attributed to high prevalence of deficiency of these two trace elements in Iranian general population [40]. Low levels of vitamin D were previously reported in thalassemic patients $[41,42]$; however its prevalence among our thalassemic patients was more than most of other reports. It may be due to high prevalence of vitamin $\mathrm{D}$ deficiency in general population.

\section{Conclusion}

High prevalence of endocrine and metabolic complications among our thalassemics signifies the importance of therapeutic interventions. The differences of these abnormalities in different series of patients may be due to variations in treatment protocols or different susceptibilities and demand more detailed studies.

\section{Authors' Contributions}

Dr AA Shamshirsaz designed the draft questionnaires and study protocol, managed the coordination of the surveys and drafted the manuscript. Dr Bekheirnia conceived of and designed the study, performed the statistical analysis, drafted the manuscript and helped design the protocol. Dr Kamgar participated in drafting the manuscript and data collection; coordinated the study and designed the protocol. Dr Pourzahedgilani participated in physical exam, filled out questionnaires and searched scientific sources. Dr Bouzari helped draft the manuscript, participated in statistical analysis and managed paraclinical surveys. Dr Habibzadeh helped in data collection and physical examination. Dr Hashemi and AHA Shamshirsaz took part in physical exams and filling questionnaires. Dr Homayoun helped design the study. Dr Larijani facilitated the study design and progress; and managed the paraclinical surveys.

All authors read and approved the final manuscript.

\section{Acknowledgments}

This study was funded by Charity Foundation for Special Diseases. The authors wish to thank all the thalassemic patients who participated in this study; clinical laboratory of Endocrinology and Metabolism Research Centre at Shariati hospital for performing the laboratory analyses.

\section{References}

I. Cooley TB, Lee P: A series of cases of splenomegaly in children with anemia and peculiar changes. Trans Am Pediatr Soc 1925, 37:29-30.

2. Saka N, Sukur M, Bundak R, Anak S, Neyzi O, gedikoglu G: Growth and puberty in thalassemia major. J Pediatr Endocrinol Metab 1995, 8: | $8 \mid-186$.

3. Modell B, Letsky EA, Flynn DM, Peto R, Weatherall DJ: Survival and desferrioxamine in thalassemia major. BM] I982, 284: $108 \mid-1084$.

4. Jensen CE, Tuck SM, Agnew JE, Koneru S, Morris RW, Morris RW, Yardumian A, Prescott E, Hoffbrand AV, Wonke B: High prevalence of low bone mass in thalassaemia major. $B$ J Haemat 1998, 103:911-915.

5. Vullo C, De Sanctis V, Katz M, Wonke B, Hoffbrand AV, Bagni B, Torresani T, Tolis G, Masiero M, Di Palma A, Borgatti L: Endocrine abnormalities in thalassemia. Ann NY Acad Sci 1990, 61 2:293-310

6. Soliman A, Banna N, Abdel Fattah M, ElZalabani MM, Ansari BM: Bone mineral density in prepubertal children with $\beta$-tha- 
lassemia: correlation with growth and hormonal data. Metabol 1998, 47:54I-548.

7. Fuchs GJ, Tienboon $P$, Linpisarn $S$, Nimsakul $S$, Leelapat $P$, Tovanabutra S, Tubtong V, DeWier M, Suskind RM: Nutritional factors and thalassemia major. Arch Dis Child 1996, 74:224-7.

8. Bashir NA: Serum zinc and copper levels in sickle cell anaemia and beta-thalassaemia in North Jordan. Ann Trop Paediatr 1995, I5:29I-3.

9. De Sanctis $V$, Wonke B: Aetiology of growth retardation in thalassemia major. In Growth in thalassemia, Roma: Mediprint 1994:39.

10. Tanner MM, Whitehouse RH: Clinical longitudinal standards for height, weight, height velocity, weight velocity, and stages of puberty. Arch Dis Child 1976, 5 I: I70-I79.

1I. Smith JC Jr, Butrimovitz GP, Purdy WC: Direct measurement of zinc in plasma by atomic absorption spectroscopy. Clin Chem 1979, 25:|487-9|.

12. Carl A, Burtis Edward R, Ashwood Norbert W: Trace Elements; Methods for determination of Copper. In In: Tietz Textbook of Clinical Chemistry Philadelphia: WB Saunders; 1999:984.

13. Cappellini M, Cohen A, Eleftheriou A, Piga A, Porter J: Endocrine Complications in Thalassaemia Major. In: Guidelines for the Clinical Management of Thalassaemia. TIF 2000:4I-49.

14. Italian Working Group on Endocrine Complications in Non-Endocrine Diseases: Multicenter study on prevalence of endocrine complication in Thalassemia Major. Clin Endocrinal 1995, 42:58I-586.

15. Evered DC, Ormston BJ, Smith PA, Hall R, Bird T: Grade of hypothyroidism. BM] 1973, I:657-662.

16. Kwan EY, Lee AC, Li AM, Tam SC, Chan CF, Lau YL, Low LC: A cross-sectional study of growth, puberty and endocrine function in patients with thalassaemia major in Hong Kong. J Paediatr Child Health 1995, 3 I:83-7.

17. Chern JPC, Lin KH, Lu MY, Lin DT, Lin KS, Chen JD, Fu CC: Abnormal glucose tolerance in transfusion-dependent beta-thalassemic patients. Diabetic care 200I, 24:850-4.

18. Magro S, Puzzanio P, Consarino C, Galati MC, Morgione S, Porcelli D, Grimaldi S, Tancre D, Arcuri V, De Santis V: Hypothyroidism in patients with thalassemia syndromes. Acta Haematol (Basel) 1990, 84:72-6.

19. Sabato AR, De Sanctis V, Atti G, Capra L, Bagni B, Vullo C: Primary hypothyroidism and the low $T 3$ syndrome in thalassemia major. Arch Dis Child 1983, 58: 120-7.

20. Depaz G, Deville A, Coussement N, Manassero J, Mariani R: Thyroid function in thalassemia major. Ann Pediatr (Paris) 1985 32:809-II.

21. Phenekos C, Karamerou A, Pipis P, Constantoulakis M, Lasaridis J, Detsi S, Politou K: Thyroid function in patients with homozygous $\beta$-thalassemia. Clin Endocrinol (Oxf) 1984, 20:445-50.

22. Landau H, Matoth I, Landau-Cordova Z, Goldfarb A, Rachmilewitz EA, Glaser B: Cross-sectional and longitudinal study of the pituitary-thyroid axis in patients with thalassaemia major. Clin Endocrinol (Oxf) 1993, 38:55-61.

23. De Sanctis V, Vullo C, Katz M, Wonke B, Hoffbrand VA, Di Palma A, Bagni B: Endocrine complications in thalassemia major. In In Advances and Controversies in Thalassemia Therapy Edited by: Buckner CD, Gale RP, Lucarelli G. New York: Alan Liss; 1989:77-83.

24. De Sanctis V, Wonke B: Growth and endocrine complications. In In Growth and endocrine complications in thalassemia Roma: Mediprint; 1998: 17-30

25. Flynn DM, Fairney A, Jackson D, Clayton BE: Hormonal changes in thalassemia major. Arch Dis child 1976, 5 I:828-36.

26. Pignatti CB, De Stefano P, Zonta L, Vullo C, De Sanctis V, Melevend C, Naselli A, Masera G, Terzoli S, Gabutti V, Piga A: Growth and sexual maturation in thalassemia major. J Pediatr 1985 106: $150-5$

27. Canale VC, Steinherz P, New M, Erlandson M: Endocrine function in thalassemia major [Abstract]. Ann NY Acad Sci 1974, 232:333.

28. Costin G, Kogut M, Hyman CB, Ortega J: Endocrine abnormalities in thalassemia major. Am J Dis Chil 1979, 133:497-502.

29. Suda K: Hemosiderin deposition in the pancreas. Arch Pathol Lab Med 1985, 109:996-999.

30. Masala A, Meloni T, Gallisai D, Alagna S, Rovasio PP, Rassu S, Milia AF: Endocrine functioning in multitransfused prepubertal patients with homozygous beta thalassemia. J Clin Enocrinol Metab 1984, 58:667-70.
31. Zervas A, Katopodi A, Protonotariou A, Livadas S, Karagiorga M, Politis C, Tolis G: Assessment of thyroid function in two hundred patients with beta-thalassemia major. Thyoid 2002, I2:15I-4.

32. Olivieri NF, Nathan DG, MacMillan JH, Wayne AS, Liu PP, McGee A Martin M, Koren G, Cohen AR: Survival in medically treated patients with homozygous $\beta$-thalassemia. N Engl J Med 1994, 331:574-578.

33. Molyvda-Athanassopoulou E, Sioundas A, Karatzas N, aggelaki M, Pazaitou K, Vainas I: Bone mineral density of patients with thalassemia major: four-year follow-up. Calcif Tissue Int 1999, 64:48I-484

34. Voskaridou E, Kyrtsonis MC, Terpos E, Skordili M, Theodoropoulos I, Bergele A, Diamanti E, Kalovidouris A, Loutradi A, Loukopoulos D: Bone resorption is increased in young adults with thalassemia major. $\mathrm{Br}$ J Haemaol 200 I, I I 2:36-4I.

35. Jensen CE, Tuck SM, Agnew JE: High prevalence of low bone mass in thalassemia major. Br J Hematol 1998, 103:9। I-9/5.

36. Anapliotou ML, Kastanias IT, Psara P, Evangelou EA, Liparaki M, Dimitriou P: The contribution of hypogonadism to the development of osteoporosis in thalassemia major: new therapeutic approaches. Clin Endocrinol 1995, 42:279-287.

37. Garofalo F, Piga A, Lala R, Chiabotto S, Di Stefano M, Isala GC: Bone metabolism in thalassemia [Abstract]. Ann NY Acad Sci 1998 , 850:475-478

38. Theodoridis C, Ladis V, Papatheodorou A, Berdousi H, Palamidou F Evagelopoulou C, Athanassaki K, Konstantoura O, Kattamis C: Growth and management of short stature in thalassaemia major. J Pediatr Endocrinol Metab 1998, Suppl 3:835-44

39. Arcasoy A, Cavdar AO, Ertug H, Gurpinar F, Prasad AS, Cavdar AO, Brewer G], Aggett PJ, eds: Zinc deficiency in human subjects. NewYork: Alan R Liss Inc 1983:107-16.

40. Mahmoodi MR, Kimiagar SM: Prevalence of zinc deficiency in junior high school students of Tehran City. Biol Trace Elem Res 200I, 8I(2):93-103.

4I. Bielinski BK, Darbyshire PJ, Mathers L, Crabtree NJ, Kirk JM, Stirling $\mathrm{HF}$, Shaw NJ: Impact of disordered puberty on bone density in beta thalassemia major. Br J Hematol 2003, 120:353-8.

42. Tsitoura S, Amarilio N, Lapatsani P, Pantelakis S, Doxiadis S: Serum 25 hydroxy vitamin D levels in thalassemia. Arch Dis Child 1978 , 53:347.

\section{Pre-publication history}

The pre-publication history for this paper can be accessed here:

http://www.biomedcentral.com/1472-6823/3/4/prepub

Publish with BioMed Central and every scientist can read your work free of charge

"BioMed Central will be the most significant development for disseminating the results of biomedical research in our lifetime. "

Sir Paul Nurse, Cancer Research UK

Your research papers will be:

- available free of charge to the entire biomedical community

- peer reviewed and published immediately upon acceptance

- cited in PubMed and archived on PubMed Central

- yours - you keep the copyright

Submit your manuscript here:

http://www.biomedcentral.com/info/publishing_adv.as
BiolMedcentral 